\title{
Chromosome numbers of eight Carex taxa in Korea (Cyperaceae)
}

\author{
Kyong-Sook CHUNG* and Gyu Young CHUNG ${ }^{1 *}$ \\ Department of Medicinal Plant Science, Jungwon University, Goesan 28024, Korea \\ ${ }^{1}$ Division of Horticulture and Medicinal Plant, Andong National University, Andong 36729, Korea \\ (Received 2 September 2021; Revised 8 September 2021; Accepted 14 September 2021)
}

\begin{abstract}
In the flora of Korea, Carex L. is one of the most species-rich genera. Among nearly 157 Carex taxa, less than 30 have had their chromosome numbers reported. We report the meiotic chromosome numbers of eight Carex taxa from Korean populations, which include the first count for C. accrescens Ohwi $\left(n=37_{\text {II }}\right)$ and the first chromosome investigations of Korean populations for three taxa: C. bostrychostigma Maxim. $\left(n=22_{\text {II }}\right)$, C. lanceolata Boott $\left(n=36_{\text {II }}\right)$, and C. paxii Kük. $\left(n=38_{\text {II }}\right)$. In most species, chromosome counts observed in the study are included within the variation ranges of previous chromosome numbers. However, C. bostrychostigma Maxim. $\left(n=22_{\mathrm{II}}\right)$ and $C$. planiculmis Kom. $\left(n=29_{\mathrm{II}}\right)$ are assigned new chromosome numbers. Carex is known to have holocentric chromosomes, lacking visible primary constrictions and exhibiting great variance in its chromosome number. Further investigations of the diversity of Carex chromosomes will provide basic information with which to understand the high species diversity of the genus.
\end{abstract}

Keywords: Carex, meiotic chromosome number, Cyperaceae

Carex L. is one of the most species diverse genera in flowering plants with more than 2,000 species worldwide (Global Carex Group, 2015). Along the great species diversity, the genus has high intraspecific variation in chromosome numbers due to holocentric chromosomes, which have diffused or nonlocalized centromeres (Hipp et al., 2009; Escudero et al., 2012). Within the genus, chromosome numbers dramatically vary, from $n=6$ to $n=66$; and taxa with high variations in chromosome numbers within species and/or individuals have been detected in recently diverging lineages (Tanaka, 1949; Roalson, 2008; Hipp et al., 2009). The chromosome features can have chromosome number increases (fission, agmatoploidy) and/or decreases (fusion, symploidy) without DNA duplication/ deletion events (Hipp et al., 2013). Genome size and chromosome number in Carex have been hypothesized to be decoupled evolutionary features (Chung et al., 2012). The cytological features are critical to understand species richness of Carex (Hipp et al., 2009; Global Carex Group, 2015).

In the flora of Korea, Carex is the largest genus with about 157 taxa in Cyperaceae, the second largest family with 246 species in 13 genera (Oh, 2007). Although chromosome information is critical to understand diversity in Carex, most species have not been investigated using cytological tools. Among Korean native taxa, only 24 Carex taxa have been reported with chromosome numbers, and the genome sizes of 43 Carex taxa have been estimated (Chung and Im, 2019; Lee et al., 2019). The cytological information is too little to understand Carex diversity in the flora.

In the present study, we report meiotic chromosome numbers of eight Carex taxa observed from Korean populations: $C$. accrescens Ohwi, C. lanceolata Boott, C. bostrychostigma Maxim., C. breviculmis R. Br., C. polyschoena H.Lév. \& Vaniot, C. sabynensis Less. ex Kunth, C. planiculmis Kom., and $C$. paxii Kük.

\section{Materials and Methods}

Immature male spikes were used for meiotic chromosome number observation. Entire spikes were preserved in a fixative containing methanol, chloroform, and propionic acid (6:3:2) and then transferred to $70 \%$ ethanol (Rothrock and Reznicek, 1996; Chung et al., 2016). Fixed anthers were squashed in $1 \%$ acetic-

\footnotetext{
*Author for correspondence: kchung@jwu.ac.kr, gychung@andong.ac.kr
} 
orcein and observed at 1,000× magnification (Nikon Eclipse 50i, Nikon, Tokyo, Japan). To determine chromosome numbers and variation ranges, more than two meiotic division cells per individual were observed, analyzed, and photographed. Taxon identification followed Park et al. (2016) and Hoshino et al. (2011), and infrageneric classification was adopted from Global Carex Group (2020). Voucher specimens with mature perigynia were stored at Andong National University herbarium $(\mathrm{ANH})$.

\section{Results and Discussion}

Meiotic chromosome numbers of eight Carex taxa were summarized in Table 1. Sections and species were organized in alphabetical order. All the species exhibited consistent chromosome numbers within individuals and had the normal bivalents paring in meiotic division. Among the four species observed more than one population, $C$. bostrychostigma and $C$. sabynensis did not exhibit variation in chromosome number. However, two $C$. planiculmis individuals had variation with $n=$ $29_{\text {II }}$ and $30_{\text {II }}$, and C. breviculmis varied in the meiotic chromosome numbers with $33_{\text {II }}, 34_{\text {II }}$, and $36_{\text {II. }}$ Their chromosomes were about $2 \mu \mathrm{m}$ long, and constricted centromeres were not visible (Fig. 1).

Carex accrescens Ohwi 경성사초 $\left(n=37_{\text {III }}\right)$ (Fig. 1A) Sect. Ammoglochin Dumortier

Meiotic chromosome number of $n=37_{\text {II }}$ was observed in $C$. accrescens (= C. pallida C. A. Mey.), which was the first count for the species. The species is characterized with long rhizomes, two types of spikes (male and androgynous) and ovoid perigynia with serrulate margins (Park et al., 2016; Hoshino et al., 2011). It occurs in East Asia, and most populations in

Table 1. Summary of chromosome number of the Carex taxa investigated in this study and reported in previous studies.

\begin{tabular}{|c|c|c|c|}
\hline Section & Species, locality, and voucher information & $\begin{array}{l}\text { Chromosome } \\
\text { number in this } \\
\text { study, } 2 n\end{array}$ & Previous counts, $2 n$ \\
\hline Ammoglochin & $\begin{array}{l}\text { C. accrescens 경성사초 (=C. pallida C.A.Mey.) } \\
\text { Socheon-myeon, Bonghwa-gun, Gyeongbuk, } 22 \text { May 2021, } \\
\text { Chung } 8023\end{array}$ & $74\left(n=37_{\mathrm{II}}\right)$ & None \\
\hline Clandestinae & $\begin{array}{l}\text { C. lanceolata 그늘사초 } \\
\text { Anseo-dong, Cheonan-si, Chungnam, } 15 \text { April 2021, Chung } 7006\end{array}$ & $72\left(n=36_{\text {II }}\right)$ & $\begin{array}{l}70 \text { (Hoshino, 1981), } 72 \text { (Hoshino and } \\
\text { Ikeda, 2003) }\end{array}$ \\
\hline Debiles & $\begin{array}{l}\text { C. bostrychostigma 길뚝사초 } \\
\text { Mt. Baebawisan, Socheon-myeon, Bonghwa-gun, Gyeongbuk, } 22 \\
\text { May } 2021 \text {, Chung } 8018 \\
\text { Same locality, } 22 \text { May } 2021 \text {, Chung } 8019\end{array}$ & $\begin{array}{l}44\left(n=22_{\mathrm{II}}\right) \\
44\left(n=22_{\mathrm{II}}\right)\end{array}$ & 46 (Hoshino et al., 2011) \\
\hline \multirow[t]{3}{*}{ Mitratae } & $\begin{array}{l}\text { C. breviculmis 청사초 } \\
\text { Anseo-dong, Cheonan-si, Chungnam, } 11 \text { April 2021, Chung } 7176 \\
\text { Baekgok-myeon, Jincheon-gun, Chungbuk, } 13 \text { April 2021, Chung } \\
\quad 7219 \\
\text { Mt. Baebawisan, Socheon-myeon, Bonghwa-gun, Gyeongbuk, } 19 \\
\quad \text { April 2021, Chung } 7323 \\
\text { Ihoil-dong, Jeju-si, Jeju, } 10 \text { April 2021, Chung } 7344\end{array}$ & $\begin{array}{l}72\left(n=36_{\text {II }}\right) \\
66\left(n=33_{\mathrm{II}}\right) \\
66\left(n=33_{\mathrm{II}}\right) \\
68\left(n=34_{\mathrm{II}}\right)\end{array}$ & $\begin{array}{l}54 \text { (Chung et al., 2016, reported as } C \text {. } \\
\text { leucochlora), c.64 (de Lange and Murray, } \\
\text { 2002), } 66 \text { (Chung et al., 2017), } 66 \text { (Chung } \\
\text { et al., 2018), 64, } 68 \text { (Tanaka, 1939), } 68 \\
\text { (Hoshino, 1981 reported as C. } \\
\text { leucochlora), } 68 \text { (Ohkawa and Yokota, } \\
1998 \text { reported as C. leucochlora), 68, 66, } \\
64 \text { (Chung and Im, 2020), } 72 \text { (Okuno, } \\
\text { 1939) }\end{array}$ \\
\hline & $\begin{array}{l}\text { C. polyschoena 가지청사초 } \\
\text { Baekgok-myeon, Jincheon-gun, Chungbuk, } 3 \text { May 2021, Chung } \\
7215\end{array}$ & $74\left(n=37_{\mathrm{II}}\right)$ & $\begin{array}{l}52 \text { (Chung et al., 2016), } 72,74 \text { (Chung et } \\
\text { al., 2018), 74, } 76 \text { (Chung and Im, 2020) }\end{array}$ \\
\hline & $\begin{array}{l}\text { C. sabynensis 실청사초 } \\
\text { Anseo-dong, Cheonan-si, Chungnam, } 15 \text { April 2021, Chung } 7200 \\
\text { Same locality, } 15 \text { April 20201, Chung } 7203\end{array}$ & $\begin{array}{l}56\left(n=28_{\text {II }}\right) \\
56\left(n=28_{\text {II }}\right)\end{array}$ & $\begin{array}{l}40 \text { (Krogulevich, 1971), } 54 \text { (Chung et al., } \\
2016), 54 \text { (Chung and Im, 2020), 54, } 56 \\
\text { (Chung et al., 2018), } 60 \text { (Yurtsev and } \\
\text { Zhukova, 1982), } 76 \text { (Chung et al., 2017) }\end{array}$ \\
\hline Molliculae & $\begin{array}{l}\text { C. planiculmis 그늘흰사초 } \\
\text { Socheon-myeon, Bonghwa-gun, Gyeongbuk, } 22 \text { May 2021, } \\
\quad \text { Chung } 8012 \\
\text { Same locality, } 22 \text { May 2021, Chung } 8016\end{array}$ & $\begin{array}{l}58\left(n=29_{\text {II }}\right) \\
60\left(n=30_{\mathrm{II}}\right)\end{array}$ & $\begin{array}{l}60 \text { (Chung and Im, 2018), } 62 \text { (Tanaka, } \\
1939 \text { ) }\end{array}$ \\
\hline Phleoideae & $\begin{array}{l}\text { C. paxii 대구사초 } \\
\text { Beopsu-myeon, Haman-gun, Gyeongnam, } 30 \text { April 2021, Chung } \\
8047\end{array}$ & $76\left(n=38_{\mathrm{II}}\right)$ & 76 (Hoshino, 1981, 1986) \\
\hline
\end{tabular}




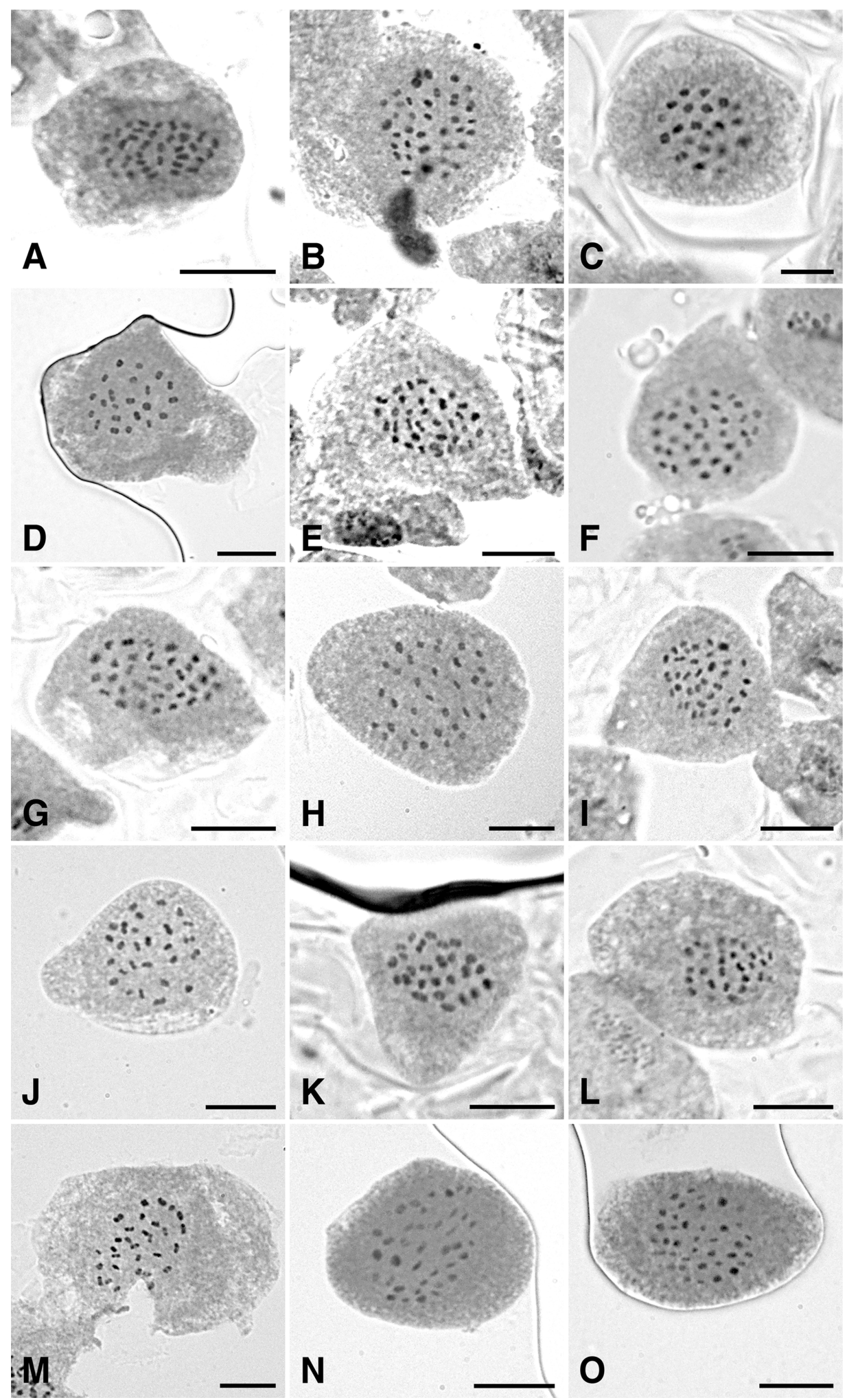

Fig. 1. Photomicrographs of Carex meiotic chromosomes. A. C. accrescens $\left(n=37_{\mathrm{II}}\right.$, Chung 8023). B. C. lanceolata $\left(n=36_{\mathrm{II}}\right.$, Chung 7006$)$. C. C. bostrychostigma $\left(n=22_{\mathrm{II}}\right.$, Chung 8018). D. C. bostrychostigma $\left(n=22_{\mathrm{II}}\right.$, Chung 8019). E. C. breviculmis $\left(n=36_{\mathrm{II}}\right.$, Chung 7176$)$. F. C. breviculmis $\left(n=33_{\mathrm{II}}\right.$, Chung 7219). G. C. breviculmis $\left(n=33_{\mathrm{II}}\right.$, Chung 7323). H. C. breviculmis $\left(n=34_{\mathrm{II}}\right.$, Chung 7344). I. C. polyschoena $(n=$ $37_{\mathrm{II}}$, Chung 7215). J. C. sabynensis $\left(n=28_{\mathrm{II}}\right.$, Chung 7200$)$. K. C. sabynensis $\left(n=28_{\mathrm{II}}\right.$, Chung 7203). L. C. planiculmis $\left(n=29_{\mathrm{II}}\right.$, Chung 8012). M. C. planiculmis $\left(n=30_{\mathrm{II}}\right.$, Chung 8016). N, O. C. paxii $\left(n=38_{\mathrm{II}}\right.$, Chung 8047). Scale bars $=10 \mu \mathrm{m}$. 
Korea are found in wet and sandy habitats (Hoshino et al., 2011; Park et al., 2016; Japanese Society of Cyperology, 2018). Global Carex Group (2020) places the species in Disticha clade with total 27 taxa, which are treated in various traditional sections, Ammoglochin, Divisae, Holarrhenae, Foetidae, Phaestoglochin, and Phleoideae.

Carex lanceolata Boott 그늘사초 $\left(n=36_{\text {III }}\right)$ (Fig. 1B) Sect. Clandestinae G. Don

For the first time, chromosome number of $C$. lanceolata from a Korean population was counted, $n=36_{\text {II. }}$. Previous counts from Japanese populations are two numbers, $2 n=70$ and $2 n$ $=72$ (Hoshino, 1981; Hoshino and Ikeda, 2003). In both South Korea and Japan, the species commonly grows (Park et al., 2016; Japanese Society of Cyperology, 2018). The species is classified in sect. Clandestinae by traditional and phylogenetic criteria (Global Carex Group, 2020).

Carex bostrychostigma Maxim. 길뚝사초 $\left(n=22_{\text {II }}\right)$ (Fig. 1C, D) - Sect. Debiles (J. Carey) Ohwi

From two individuals of $C$. bostrychostigma, chromosome numbers of $n=22_{\text {II }}$ were observed, which were first counts from Korean populations and different from the previous report from a Japanese population ( $2 n=46$ in Hoshino et al., 2011). In South Korea, the species is very common occurring throughout the country, whereas it is found only in Honshu and Kyushu in Japan (Park et al., 2016; Japanese Society of Cyperology, 2018). More investigations targeting broad distribution areas should be conducted to determine chromosome number variation range in the species. Global Carex Group (2020) places the species in Dissitiflora clade with $C$. dissitiflora Franch., which is endemic to Japan and traditionally in sect. Mundae $(2 n=36,38)$ (Hoshino et al., 2011).

Carex breviculmis R.Br. 청사초 $\left(n=33_{\mathrm{II}}, 34_{\mathrm{II}}, 36_{\mathrm{II}}\right)$ (Fig. 1E-H) - Sect. Mitratae Kükenthal

Three different chromosome numbers were observed from four populations. Chromosome numbers of $n=33_{\text {II }}$ and $n=$ $34_{\text {II }}$ are previously reported from Korean populations (Chung et al., 2017, 2018; Chung and Im, 2020), but $n=36_{\text {II }}$ is the first count from a Korean population, which is previously reported from Japanese populations (Okuno, 1939). The species relatively common in Korea and Japan, occurring in Asia such as Taiwan, Russia, and Himalaya (Park et al., 2016; Japanese Society of Cyperology, 2018). Traditionally the species is classified in sect. Mitratae Kük., and recent classification shows that the species forms a clade named Mitrata with majority of Mitratae members (Global Carex
Group, 2020). High chromosome variation in the species, from $2 n=54$ to $2 n=72$ (not continuous), might be related with broad distribution or with confuse of taxonomic complex such as species delimitation.

Carex polyschoena H.Lév. \& Vaniot 가지청사초 $\left(n=37_{\text {II }}\right)$ (Fig. 1I) - Sect. Mitratae Kükenthal

Chromosome number of $n=37_{\text {II }}$ was observed for $C$. polyschoena. The species is only found in Korea and Japan. In South Korea, the species is very common occurring throughout the country, whereas the species occurs only in Tsushima, Kyushu, Japan (Hoshino et al., 2011; Park et al., 2016). Various chromosome numbers for the species have been reported from Korean populations $(2 n=52,72,74,76)$ (Chung et al., 2016, 2018; Chung and Im, 2020). The species is classified in Conica clade with 48 species, which are mainly Mitratae members distributed in Asia (Global Carex Group, 2020).

Carex sabynensis Less. ex Kunth 실청사초 $\left(n=28_{\text {II }}\right)$ (Fig. 1J, K) - Sect. Mitratae Kükenthal

Chromosome number of $n=28_{\text {II }}$ was observed from two individuals of $C$. sabynensis, which was identical to the previous report from a Korean population in Chung et al. (2016). Five different chromosome numbers have been reported for the species $(2 n=40,54,56,60,76)$ (Table 1). The species occurs throughout the country in South Korea, whereas it grows in Hokkaido, Honshu, and Kyushu in Japan (Hoshino et al., 2011; Park et al., 2016). It is also found in China and Russia (Park et al., 2016). Global Carex Group (2020) classifies the species in Conica clade, where $C$. polyschoena belonging to.

Carex planiculmis Kom. 그늘흰사초 $\left(n=29_{\text {II }}, 30_{\text {II }}\right)$ (Fig. 1L, M) - Sect. Molliculae Ohwi

Two chromosome numbers for $C$. planiculmis were observed, $n=29_{\text {II }}$ and $n=30_{\text {II }}$. The chromosome number of $n=29_{\text {II }}$ is a new count for the species. Chromosome number of the species ranges from $2 n=58$ to $2 n=62$, including observations made from Japanese and Korean populations ( $2 n$ $=62$, Tanaka, 1939; $2 n=60$, Chung and Im, 2018). The species occurs in East Asia including north part of Japan (Honshu and Hokkaido) and most provinces in Korea (Park et al., 2016; Japanese Society of Cyperology, 2018). Traditionally, the species is classified in sect. Molliculae and the section is well supported in phylogenetic research. However, C. planiculmis position in the section is not supported by phylogenetic data and remains unresolved (Global Carex Group, 2020). 
Carex paxii Kük. 대구사초 $\left(n=38_{\text {II }}\right)($ Fig. $1 N$, O) - Sect. Phleoideae Meinshausen

For the first time, a chromosome number of $C$. paxii from a Korean population was counted, which was identical to the previous count made from Japanese populations (Hoshino, 1981, 1986). In both Japan and Korea, only a few natural populations have been reported, and the species also occurs in China (Park et al., 2016; Japanese Society of Cyperology, 2018). The species has been classified in sect. Phleoideae in traditional classification, but the phylogenetic data have moved it to Disticha clade composed of some numbers of six traditional sections (two Ammoglochin, one Divisaae, ten Holarrhenae, nine Foetidae, four Phaestoglochin, and one Phleoideae taxa) (Global Carex Group, 2020). Among nine taxa in the traditional section Phleoideae, C. paxii is the only species not supported by the sectional classification but is grouped with North American and Eurasian species in Disticha clade (Global Carex Group, 2020).

Most Carex species are assigned in revised phylogenetic classification, but many clades miss morphological and/or geographic synapomorphies (Global Carex Group, 2020). It is unlikely that a single character would explain lineage divergences, but combinations of characters might be able to interpret current lineages. Chromosome variation within species is common in the genus, and genetic diversity explains lineage diversity and limitations in some lineages with enough cytological data available (Hipp et al., 2009; Chung et al., 2012). It is challenging to obtain cytological information due to living material availability and maintenance. However, further work on cytological data is critical to understand infrageneric lineage and species diversity in the genus.

ORCID: Kyong-Sook CHUNG https://orcid.org/0000-00024464-4698; Gyu Young CHUNG https://orcid.org/0000-00024891-1140

\section{Acknowledgments}

This study was supported in part by the National Research Foundation of Korea (NRF-2018R1A2B6008851).

\section{Conflict of Interest}

The authors declare that there are no conflicts of interest.

\section{Literature Cited}

Chung, K.-S. and H.-T. Im. 2018. Meiotic chromosome numbers of five Carex taxa in Korea (Cyperaceae). Korean Journal of Plant Taxonomy 48: 201-205.

Chung, K.-S. and H.-T. Im. 2019. Report on the chromosome numbers of four Carex taxa (Cyperaceae). Korean Journal of Plant Taxonomy 49: 269-273.

Chung, K.-S. and H.-T. Im. 2020. Chromosome number report of three Carex sect. Mitratae taxa (Cyperaceae) in Korea. Koran Journal of Plant Taxonomy 50: 361-367.

Chung, K.-S., A. L. Hipp and E. H. Roalson. 2012. Chromosome number evolves independently of genome size in a clade with nonlocalized centromeres (Carex: Cyperaceae). Evolution 69: 2708-2722.

Chung, K.-S., T. Hoshino, T. Masaki and H.-T. Im. 2017. Cytological investigations on eight Carex species in Korea (Cyperaceae). Cytologia 82: 329-334.

Chung, K.-S., T. Hoshino, T. Masaki, H.-T. Im and S.-J. Ji. 2018. Chromosome counts of six Korean Carex species (Cyperaceae). Cytologia 83: 229-233.

Chung, K.-S., T. Hoshino, T. Masaki, J. C. Yang and H.-T. Im. 2016. Cytological studies on seven species of Korean Carex (Cyperaceae). Cytologia 81: 143-147.

de Lange, P. J. and B. G. Murray. 2002. Contributions to a chromosome atlas of the New Zealand flora: 37. Miscellaneous families. New Zealand Journal of Botany 40: 1-23.

Escudero, M., A. L. Hipp, M. J. Waterway and L. M. Valente. 2012. Diversification rates and chromosome evolution in the most diverse angiosperm genus of the temperate zone (Carex, Cyperaceae). Molecular Phylogenetics and Evolution 63: 650655.

Global Carex Group. 2015. Making Carex monophyletic (Cyperaceae, tribe Careiceae): A new broader circumscription. Botanical Journal of the Linnean Society 179: 1-42.

Global Carex Group. 2020. A framework infrageneric classification of Carex (Cyperaceae) and its organizing principles. Journal of Systematics and Evolution 59: 726-762.

Hipp, A. L., M. Escudero and K.-S. Chung. 2013. Holocentric chromosomes. In Encyclopedia of Genetics. 2nd ed. Vol. 3. Maloy, S. and K. Hughes (eds.), Elsevier, New York. Pp. 499 501.

Hipp, A. L., P. E. Rothrock and E. H. Roalson. 2009. The evolution of chromosome arrangements in Carex (Cyperaceae). Botanical Review 75: 96-109.

Hoshino, T. 1981. Karyomorphological and cytogenetical studies on aneuploidy in Carex. Journal of Science of the Hiroshima University, Series B Division 2 17: 155-238.

Hoshino, T. 1986. A cytotaxonomical study of Carex paxii and two allied species. Journal of Japanese Botany 61: 161-164.

Hoshino, T. and H. Ikeda. 2003. A new species of Carex (Cyper- 
aceae), C. bitchuensis, from Okayama Prefecture, Japan. Journal of Japanese Botany. 78: 24-28.

Hoshino, T., T. Masaki and M. Nishimoto. 2011. Illustrated Sedges of Japan. Heibonsha Ltd., Tokyo.

Japanese Society of Cyperology. 2018. Distribution Maps of Carex (Cyperaceae) in Japan. Masaki, T. (ed.), Japanese Society of Cyperology, Okayama. (in Japanese)

Krogulevich, R. E. 1971. The role of polyploidy in the genesis of the alpine flora of the Stanovoye Nagorye Mountains. In The Ecology of the Flora of the Trans-Baikal Region. Krogulevich, R. E. and A. A. Gorshkov (eds.), USSR Academy of Sciences, Irkutsk. Pp. 115-214.

Lee, B., Y. Cho and S. Kim. 2019. Genome size estimation of 43 Korean Carex. Korean Journal of Plant Taxonomy 49: 334344.

Oh, Y. C. 2007. Cyperaceae Juss. In The Genera of Vascular Plants of Korea. Park, C.-W. (ed.), Academy Publishing Co., Seoul. Pp. 1113-1181.

Ohkawa, T. and M. Yokota. 1998. Chromosome numbers and their variation patterns of Carex in the Ryukyu Islands. Cytologia 63: 447-457.

Okuno, S. 1939. Chromosome numbers in the genus Carex. Jap- anese Journal of Generics 15: 332-333. (in Japanese).

Park, S.-H., Y.-M. Lee, H.-J. Kim, J.-C. Yang, C.-S. Jang, K.-H. Lee, J.-S. Lee, J.-S. Han, H.-J. Kim, K.-S. Jeong, D.-C. Son, D.-H. Lee, M.-J. Joo, E.-M. Sun, C.-H. Shin, K. Choi, S.-H. Oh, K. S. Chang, S.-Y. Jung and S.-J. Ji. 2016. Illustrated Cyperaceae of Korea. Munyoungsa, Seoul.

Roalson, E. H. 2008. A synopsis of chromosome number variation in the Cyperaceae. Botanical Review 74: 209-393.

Rothrock, P. E and A. A. Reznicek. 1996. Documented chromosome numbers 1996:1. Chromosome numbers in Carex section Ovales (Cyperaceae) from Eastern North America. Sida 17: 251-258.

Tanaka, N. 1939. Chromosome studies in Cyperaceae IV, Chromosome number of Carex species. Cytologia 10: 51-58.

Tanaka, N. 1949. Chromosome studies in the genus Carex with special reference to aneuploidy and polyploidy. Cytologia 15 : $15-29$.

Yurtsev, B. A. and P. G. Zhukova. 1982. Chromosome numbers of some plants of the northeastern Yakutia (the drainage of the Indigirka River in its middle reaches). Botanicheskii Zhurnal 67: 778-787. 